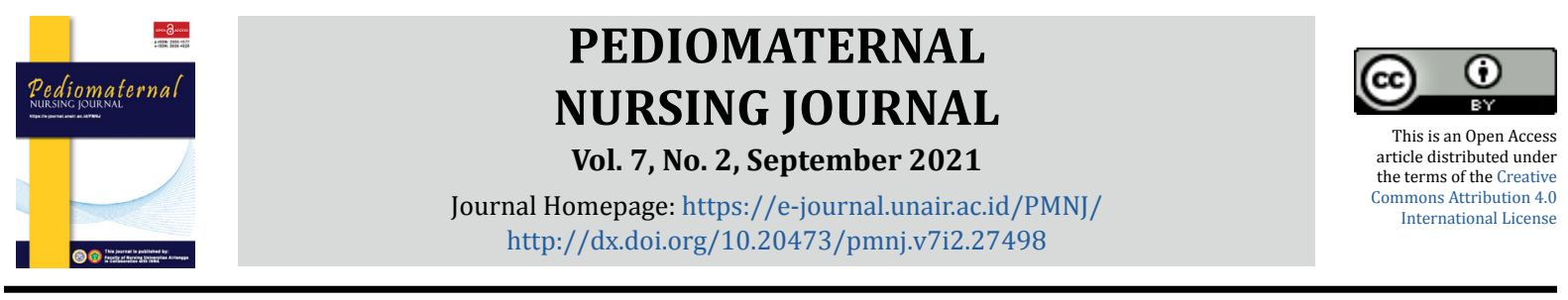

Original

\title{
The Effect of Reproductive Health Education on Knowledge and Attitudes of Adolescent About Premarital Sex in Private Vocational School Surabaya
}

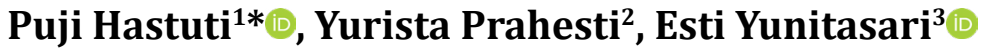 \\ ${ }^{1}$ Doctoral in Nursing Study Program, Faculty of Nursing, Universitas Airlangga, Surabaya, Indonesia \\ ${ }^{2}$ STIKES Hang Tuah Surabaya, Surabaya, Indonesia \\ ${ }^{3}$ Department of Fundamental Nursing, Faculty of Nursing, Universitas Airlangga, Surabaya, Indonesia
}

\section{ARTICLE HISTORY}

Received : June 14, 2021

Revised : August 16, 2021

Accepted : September 8, 2021

Published : September 15, 2021

\section{KEYWORDS}

reproductive health education; knowledge; attitudes

\section{CORRESPONDING AUTHOR}

*Puji Hastuti

puji.hastuti-2020@fkp.unair. ac.id

Doctoral in Nursing Study Program, Faculty of Nursing, Universitas Airlangga, Surabaya, Indonesia

Cite this as:

\begin{abstract}
Introduction: Adolescence is a period of storms and stress; health problems that occur in adolescents are related to risky behavior, namely smoking, drinking alcohol, abuse of illegal drugs and having premarital sexual relations. The research objective was to determine the effect of reproductive health education on adolescent knowledge and attitudes about premarital sex.

Methods: The research design used a quasi-experimental. The study population totalled 356 students. The sampling technique uses nonprobability sampling: purposive sampling. A sample size of 188 respondents was obtained-reproductive health education implemented by video and leaflet. Data analysis used the Wilcoxon and Mann Whitney tests with a significant level of 0.05 .

Results: The results showed that in the video group, the knowledge level was $p=0.000$, and the attitude was $p=0.000$. The leaflet group showed a level of knowledge of $p=0.000$ and an attitude of $p=0.000$. The difference between the two groups was tested by using the Mann Whitney test. It was found that there was no difference in the effect of the video and leaflet methods on knowledge of $\mathrm{p}=0.219$ and attitudes of $\mathrm{p}=0.469$.

Conclusion: Leaflets are effective for health education because they can be read individually and contain topics about premarital sex, which are more personal. The school must provide integrated sexual education with formal lessons that use many methods to increase students' knowledge.
\end{abstract}

Hastuti, P., Prahesti, Y., \& Yunitasari, E. (2021). The Effect of Reproductive Health Education on Knowledge and Attitudes of Adolescent About Premarital Sex in Private Vocational School Surabaya. Pediomaternal Nurs. J., 7(2), 101-108. Doi: http://dx.doi.org/10.20473/pmnj.v7i2.27498

\section{INTRODUCTION}

Reproductive health is healthy physically, mentally and socially, not only free from diseases or defects related to the reproductive system, function and process. The scope of reproductive health services consists of mothers and children, family planning, prevention and management of sexually transmitted infections including HIV / AIDS, adolescent reproductive health, prevention of abortion and so on (Kementrian Kesehatan RI., 2016). In some cases of abortion, some 
adolescents have had abortions more than once or repeatedly, even though they have experienced abortion as if abortion was the only way when experiencing pregnancy. This reflects adolescents' lack of knowledge about healthy life skills, the risks of premarital sexual relations and the ability to reject relationships they do not want (Kusumaningrum, 2009). Cases of pregnancy outside of marriage and immorality among students are indeed on the rise. In recent months many mass media such as newspapers, television news and radio have broadcast about students who cannot take the UN because they are pregnant.

The demographic and health survey results, especially the Adolescent Reproductive Health component, showed that the most significant proportion of first-time dating was at the age of 15-17 years. About 33.3\% of girls and $34.5 \%$ of boys aged $15-19$ years started dating when they were not yet 15 years old. The age is worrying because adolescents do not have adequate life skills and risk having unhealthy dating behavior, including premarital sexual intercourse. The survey also found the percentage of premarital sex among adolescents. In 2007 male adolescents aged $15-19$ years were $3.7 \%$ and female adolescents were $1.3 \%$. In 2012, there was an increase in the percentage of premarital sex aged 15-19 years for boys by $4.5 \%$ and for girls by $0.7 \%$ (Kementrian Kesehatan RI., 2016). The survey results found that premarital sexual relations were mostly due to curiosity or curiosity (57.5\% men), just happened (38\% women) and forced by a partner (12.6\% women). Throughout 2015, there was an increase in cases of unplanned pregnancy among East Java students, namely as many as 30 cases; previously in 2014 , there were only 23 cases. The Head of the Data and Research Division of the East Java Child Protection Agency (LPA) stated that students who experience unwanted pregnancies in the Surabaya area are between 12-18 years (Rahmawati \& Devy, 2018). Researchers are interested in researching 4 Private Vocational School X Surabaya. When conducting the preliminary study, the researcher interviewed with the Counseling Guidance Teacher that there had never been any reproductive health education about premarital sex to class X. The researcher also interviewed 20 respondents, respectively. The interviews obtained include $50 \%$ of students who are already dating and $50 \%$ of students who are not yet dating.

Sexual education is still taboo to discuss, from parents to children to teachers in schools with their students. The barriers that parents feel when providing sex education to children are the lack of knowledge on how to provide sexual education and the discomfort where parents also feel awkward discussing sex problems openly (Siregar, 2014). Lack of knowledge in adolescents can increase curiosity in adolescents; adolescents will automatically seek information about sex through magazines, the internet and social media. Social media is very closely related to teenager's life today. On social media, teenagers are free to access any site, including watching pornographic videos, this habit, if less attention from parents, can cause teenagers' desire to implement what they see. Premarital sexuality is caused by many teenagers already dating with high curiosity and a willingness to try. The wrong adolescent dating behavior can negatively impact the adolescent, which leads to premarital sexual behavior. The impact of premarital sex occurs in pregnancy in women, which results in dropping out of school due to pregnancy, increasing cases of abortion, and an increase in sexually transmitted diseases such as HIV/AIDS in Indonesia. Youth is the nation's next-generation which is expected to replace previous generations with Work quality, and mental health are better. However, it turns out that risky sexual behavior in several regions in Indonesia tends to be high.

The researchers hope that after conducting this research, the school can provide education about reproductive health and sexuality education through formal lessons to get the correct knowledge about sexual education. The school can control adolescent behavior and increase extracurricular activities in their free time. The school can also provide spiritual education or other spiritual activities according to student beliefs. Parents are expected to be more able to control and direct their young men and daughters regarding positive activities that teenagers can participate in and be more open about knowledge about sex education for children. Based on the phenomenon, the researcher desires to conduct research on the 
effect of reproductive health education on the knowledge and attitudes of adolescents about premarital sexuality at a Private Vocational School, Surabaya, East Java in 2019.

\section{METHOD}

\section{Study Design}

The type of research was quasi-experiment with a research design using pretestposttest two groups without control design. The independent variable in this study is reproductive health education. And the dependent variable in this study is adolescents' knowledge and attitudes. 2 Groups of students were measured knowledge and attitudes before being given treatment. Furthermore, 1 group was assigned health education treatment using the video method, and 1 group was given health education using the leaflet method. After the two groups were given treatment, their knowledge and attitudes were measured again.

\section{Population, Samples, and Sampling}

The population was all students of class $\mathrm{X}$ at Private Vocational School Surabaya, 356 people. The calculation of the sample size using the formula from Slovin found that the sample size used in this study was 94 groups of video method treatment and 94 groups of treatment with leaflet method. The sampling technique uses NonProbability Sampling, namely purposive sampling. The sample in this research is teenage girls at Private Vocational School Surabaya who meet the requirements. The criteria in this study are 1. Inclusion criteria: willing to be a respondent. 2. Exclusion Criteria a. Students who are sick and cannot attend the research. b. Respondents resigned during the research process.

\section{Instrument}

The data were collected using a questionnaire on the respondents' demographic data and an observation sheet containing data on the length of time the counseling took place. The questionnaireincludesquestions to measurethe level of knowledge consisting of 19 questions. The query uses the Guttman scale. There are four indicators used, namely the definition of premarital sex four questions number 1 to 4 , factors that encourage premarital sex four questions from numbers 5 to 8 , the impact of free sex six questions from numbers 9 to 14 and premarital sexual solutions five questions from number 15 to 19. Questions with correct answers are given a value of 1 , and incorrect answers are given a score of 0 . Measurement of attitudes using a questionnaire with a 4-point Likert scale contains a statement of a person's perception of existing symptoms or problems. Positive Statement Value Strongly agrees: SS 4, Agree: S 3 Disagree: TS 2 Strongly disagree: STS 1 Negative Statement Value Strongly agree: SS 1 Agree: S 2 Disagree: TS 3 Strongly disagree: STS 4. Knowledge variable categorized by Good (>75\%), Enough ( $>55 \%-75 \%$ ) and Less $(<56 \%)$. Attitude variable categorized by Negative 10-25 and Positive 26-40.

\section{Procedure}

The researcher conducted an ethical test before taking data. The researcher submitted a research permit application letter to the Principal of Senior High School Pawiyatan Surabaya. Students who are willing to become respondents are asked to sign an informed consent. Research respondents who agreed to participate in the study were given a questionnaire to fill in completely to measure the level of knowledge and attitudes before being given reproductive health education (pretest). After taking the pretest data, the researcher provided health education about the dangers of premarital sexuality with different methods, namely the experimental group 1 with video group given for 30 minutes duration, and group 2 with leaflets, in a sample of 94 respondents each according to the place and time of the activity by referring to the compiled procedure. Respondents who had been given intervention with different methods were given another questionnaire (posttest) to measure their level of knowledge and attitudes after being given reproductive health education. The post-test was carried out immediately after the intervention was given.

\section{Data Analysis}

The researcher conducted a univariate analysis with descriptive analysis, which was carried out to describe each variable under study separately by creating a frequency table of 
each variable. Furthermore, the data has been processed. Bivariate analysis is carried out with the statistical test used is the Wilcoxon \& Mann Whitney test with a significant level of 0.05 , meaning that if $p>0.05$ means the hypothesis is rejected, which means that there is no effect of reproductive health education on the knowledge and attitudes of adolescents in Senior High School Pawiyatan Surabaya.

\section{Ethical Clearance}

Approval sheets are given before the research is carried out so that respondents know the aims and objectives of the research and the impacts that will occur in data collection. The ethical approval was obtained from KEPK Stikes Hang Tuah Surabaya, PE/32/V/2019/ KEPK/SHT. The researcher did not include the subject's name on the data collection sheet provided by the respondent to maintain the confidentiality of the respondent's identity. The confidentiality of the information that has been collected from the subject is guaranteed to be strictly confidential.

\section{RESULT}

Characteristic respondents showed that mean of age in video group was 15.17 and 15.14 in leaflet group. Most of respondents in both groups were female (Table 1). Bivariate using analysis showed that there was significant between pre-test and post-test on knowledge and attitude $(\mathrm{p}<0.05)$ (Table 2, Table 3). However, there was no significant differences in both groups ( $p>0.05)$ (Table 4).

\section{DISCUSSION}

\section{The effect of reproductive health education using the video method on adolescent knowledge about premarital sex}

The results of this study, the level of knowledge of adolescents when the pretest was conducted, the majority of them had sufficient knowledge, namely as many as 84 students $(89.4 \%)$, the data obtained were 73 adolescents who did not know that feeling of attraction, dating, and holding hands with their boyfriends were premarital sexual behavior. There was one student who experienced a decrease in the level of knowledge, 64 adolescents experienced an increase in the level of knowledge, and 29 adolescents experienced a determination of the level of knowledge. Researchers assume that adolescents need to get reproductive health education about premarital sex to improve healthy life skills, the risk of sexual intercourse and the ability to refuse unwanted premarital sexual relations. After being given treatment or reproductive health education about premarital sexuality using the video method, adolescent knowledge has increased to 68 students $(72.3 \%)$ with good knowledge. The SKRRI, 2012 survey regarding adolescent information regarding reproductive health and symptoms of sexually transmitted diseases were not sufficient. The data shows that $35.5 \%$ of female adolescents and $31.2 \%$ of male adolescents aged 15-19 years know that women can get pregnant. With one sexual intercourse, while information about HIV was relatively more widely accepted by adolescents, although only $9.9 \%$ of girls and $10.6 \%$ of boys had comprehensive knowledge about HIV-AIDS. Supported by research results (Syihabudin, 2018), health education using audio-visual methods is effective at the level of knowledge.

Researchers assume that the video method visually and audio attracts the attention of adolescents so that millennial adolescents can more quickly capture it. In the concept of adolescent development, adolescents at this age are cognitively towards more mature development, where there is a change in the formal operational mindset of adolescents (Naedi, 2012). Research from (Tuong et al., 2014) on examining the effectiveness of video interventions in changing health behavior concluded that video interventions vary widely to modify health behavior depending on the target to be influenced. The video intervention in this study appears to be effective in breast self-examination, cancer screening, self-care, and medication adherence.

\section{The effect of reproductive health education using the video method on adolescent attitudes about premarital sex}

The results of this study, the majority of 
Table 1. Characteristic Respondents $(n=188)$

\begin{tabular}{|c|c|c|c|}
\hline Demographic Data & Category & Video group & Leaflet group \\
\hline \multirow[t]{2}{*}{ Age } & Mean & 15.17 & 15.14 \\
\hline & SD & 0.378 & 0.347 \\
\hline \multirow[t]{2}{*}{ Gender } & Female & $85(90.4 \%)$ & $83(88.3 \%)$ \\
\hline & Male & $9(9.6 \%)$ & $11(11.7 \%)$ \\
\hline
\end{tabular}

Table 2. The effect of video health education and leaflet health education on knowledge

\begin{tabular}{lccccccccc}
\hline & \multicolumn{4}{c}{ Video Group } & \multicolumn{3}{c}{ Leaflet Group } \\
\cline { 2 - 11 } Knowledge & \multicolumn{3}{c}{ Pre } & \multicolumn{2}{c}{ Post } & \multicolumn{3}{c}{ Pre } & \multicolumn{3}{c}{ Post } \\
\cline { 2 - 10 } & $\mathbf{n}$ & $\mathbf{0}$ & $\mathbf{n}$ & $\mathbf{\%}$ & $\mathbf{n}$ & $\mathbf{\%}$ & $\mathbf{n}$ & \% \\
\hline Less & 3 & 3.2 & 0 & 0 & 3 & 3.2 & 3 & 3.2 \\
Enough & 84 & 89.4 & 26 & 27.7 & 82 & 87.2 & 15 & 16 \\
Good & 7 & 7.4 & 68 & 72.3 & 9 & 9.6 & 76 & 80.9 \\
Wilcoxon Sign Rank Test & \multicolumn{4}{c}{$\mathrm{p}=0.000$} \\
\hline
\end{tabular}

Table 3. The effect of video health education and leaflet health education on attitude

\begin{tabular}{|c|c|c|c|c|c|c|c|c|}
\hline \multirow{3}{*}{ Attitude } & \multicolumn{4}{|c|}{ Video Group } & \multicolumn{4}{|c|}{ Leaflet Group } \\
\hline & \multicolumn{2}{|c|}{ Pre } & \multicolumn{2}{|c|}{ Post } & \multicolumn{2}{|c|}{ Pre } & \multicolumn{2}{|c|}{ Post } \\
\hline & $\mathbf{n}$ & $\%$ & $\mathbf{n}$ & $\%$ & $\mathbf{n}$ & $\%$ & $\mathbf{n}$ & $\%$ \\
\hline Positive & 59 & 62.8 & 8 & 8.5 & 67 & 71.3 & 11 & 11.7 \\
\hline Negative & 35 & 37.2 & 86 & 91.5 & 27 & 28.7 & 83 & 88.3 \\
\hline Wilcoxon Sign Rank Test & \multicolumn{4}{|c|}{$\mathrm{p}=0.000$} & \multicolumn{4}{|c|}{$p=0.000$} \\
\hline
\end{tabular}

Table 4. The differences in the effect of reproductive health education with the video method and the leaflet method on adolescent knowledge and attitude about premarital sex

\begin{tabular}{|c|c|c|c|c|}
\hline & Result & $\mathbf{n}$ & Mean & Mann-Whitney U Test \\
\hline \multicolumn{5}{|c|}{ Knowledge } \\
\hline Video & & 94 & 90.91 & $\mathrm{p}=0.219$ \\
\hline Leaflet & & 94 & 98.09 & \\
\hline \multicolumn{5}{|c|}{ Attitude } \\
\hline Video & & 94 & 96.00 & $p=0.469$ \\
\hline Leaflet & & 94 & 93.00 & \\
\hline
\end{tabular}

adolescents' attitudes during the pretest were bad, as many as 59 students $(62.8 \%)$. There were two adolescents who experienced a decline in attitudes, 53 adolescents who experienced an increase in attitudes, and 39 students who experienced attitude determination. Researchers assume that the environment of adolescents and peers influences students with bad attitudes. With new and exciting information such as this video method, adolescents begin to analyze attitudes and initiate changes to bad attitudes. A good attitude about premarital sex is possible because it follows the task of adolescent development, as stated by Hurlock, that at this time adolescents begin to acquire and understand a set of values and an ethical system as a behavior guide.

A bad attitude is a tendency to stay away from, avoid, hate, and dislike certain objects with factors including personal experience, culture, other people who are considered important, mass media, educational or religious institutions or institutions and emotional factors in individuals (Kusumastuti, 2010). This study shows that adolescents need more guidance to be able to direct their attitudes to a better one, following the task of adolescent development where at that age hormonal changes occur in reproductive function, 
resulting in the ability to hypothesize and deal with changes that occur in adolescence. At this time, adolescents begin to strengthen selfcontrol or the ability to control themselves on a scale of values, principles and philosophy of life (Pratiwi, 2012).

\section{The effect of reproductive health education using the leaflet method on adolescent knowledge about premarital sex}

The data obtained from this study were one adolescent with a decreased level of knowledge, 67 adolescents with increased knowledge levels and 26 adolescents with fixed knowledge levels. In this study, it was shown that there were nine students $(9.6 \%)$ who had a good level of knowledge before and after being given reproductive health education using the leaflet method $(9.6 \%)$ to 76 students $(80.9 \%)$. Based on the research, three students $(3.2 \%)$ had a low level of knowledge, and only $51.1 \%$ of adolescents knew that frequently meeting with their lovers could encourage premarital sexual behavior. Researchers assume that the high intensity of meeting a lover will cause curiosity and want to try something new like what they see on social information media, often meeting will lead to a feeling of love for the boyfriend will grow so that when he gets a request from a teenage girlfriend do not think long enough to obey what her lover wants. Supported by research (Hasibuan, 2013) about the factors that influence the incidence of premarital sex in young girls at SMAN 1 Pagai Utara, the results show that there is a significant relationship between the influence of pressure from boyfriends on premarital sexual incidence in young girls at SMAN 1 North Pagai. According to (Freeman et al., 2009), knowledge can be changed with persuasion strategies, namely providing information to others with health education carried out by various methods, one of which is by providing leaflets. The addition of leaflet media allows respondents to read them more clearly because they are individual (Fatmawaty, 2017). The language used by researchers in the leaflets used common language, which made it easier for teenagers to understand. Freeman et al. (2009) suggest that the use of leaflets if optimized for most health practices, will have a good impact, leaflets are used as a medium of information when the information conveyed concerns a more intimate part, as in this study, leaflets are used for helps promote early detection of genitalia. Leaflets that are individual or can be read by individuals and are also designed in a pocketsize make it easy for patients to repeat reading so that it is easier to gain new knowledge.

\section{The effect of reproductive health education using the leaflet method on adolescent attitudes about premarital sex}

The data obtained from this study shows that there are two adolescents with decreased attitudes, 58 adolescents with increased attitudes, and 34 adolescents with fixed attitudes. The bad attitude in the pretest calculation was more dominant with 67 students $(71.3 \%)$. Researchers assume that the factors that cause respondents' attitudes at the pretest are more bad attitudes due to the lack of education about premarital sex from both the health agency and the health agency itself. Another factor that can cause adolescent attitudes when the pretest is not good is the environment. The environment near the localization area or the so-called prone area is one of the factors that influence the attitudes of youth. According to (Azwar, 2013), the factors that influence attitudes are mass media as a means of communication for various forms of mass media, which have a major influence in forming people's opinions and beliefs. In conveying information about its main task, the mass media carry messages containing suggestions that can direct one's opinion. The existence of new information about something provides a basis for new cognitive thinking to form attitudes towards it. If it is strong enough, it will provide a sufficient basis in assessing something so that a confident attitude is formed. Information in the leaflet im $\neg$ proved the habit of accessing media related to reproductive health and positive premarital sexual attitudes (Damanik et al., 2020). This is also supported by research conducted by Barik et al., who suggested this form of media will be more effective when combined with other media such as videos, telephone interactions, games and others (Barik et al., 2019). 
The difference in the effect of the video method and the leaflet method on adolescent knowledge about premarital sex

There is no significant difference in reproductive health education between the video method and the leaflet method on knowledge in adolescents. However, the average value for the leaflet method is higher, namely 98.09, while the average value for the video method under the leaflet method is 90.91, which means that the use of the leaflet method is more effective than the video method. Researchers assume that when adolescents are given reproductive health education using the video method using devices such as LCDs, projectors, and sound, it will be more attractive because they get information through visuals and get information via audio. Still, the drawback is that is due to 1 LCD. Children in groups and adolescents in the back will have difficulty reading or hearing less audio because the sound is in front. Whereas in the leaflet method group, respondents received one leaflet for one person, making it very easy for respondents to read and understand the material's content.

Both the leaflet method and the video method are equally effective in increasing adolescent knowledge about the dangers of smoking, although leaflet media are more effective in increased knowledge of adolescents about the dangers of smoking compared to video. Still, the video method group also showed an average increase. Sexual health education materials are designed as easy as possible to be accepted by patients, for example distributing leaflets or by displaying them at the location that allows the patient to read. This method is the most used to distribute educational material, thus leaving the decision to have complete information on the individual patient. The practice nurse said, "Well, we have TV to play videos, but please note that most health promotion videos cover all aspects except sexual health. Obviously, there are some people who will be offended, so we also have to be careful of anything big". Opposite with the study of (Prawesti et al., 2018) that health education intervention using video has a higher impact in the development of maternal health literacy compared with the standard intervention using the brochure. This is possible because the material presented and the respondents are considered adults. Viewing the video makes it easier for them to understand the meaning of the message conveyed.

\section{The difference in the effect of the video method and the leaflet method on adolescent attitudes about premarital sex}

There is no difference in reproductive health education between the video method and the leaflet method on attitudes in adolescents. The average value for the leaflet method is 93.00, while the average value for the video method is 96.00. Researchers assume that adolescents are closely related to media served via electronic devices. Adolescents will be more interested if there is something more instantaneous. Therefore the use of the video method can influence adolescent attitudes about premarital sexuality. A scoping review from (Condran et al., 2017) suggests that the results of this study support the use of social media in sexual health promotion interventions, especially promoting environmental, individual behavior change. The most significant type of social media is youtube, which can display or provide health education through audio or visuals. Essentially the field of health promotion is intended to facilitate individuals and populations in obtaining positive health outcomes, often through action at the institutional, community and policy levels.

\section{CONCLUSION}

Reproductive health education using the video method affects the knowledge and attitudes of adolescents about premarital sexuality at Private Vocational School Surabaya. Reproductive health education using the leaflet method has an effect on the knowledge and attitudes of adolescents about premarital sex at Private Vocational School Surabaya. Reproductive health education using the video method is no different from the leaflet method in influencing the knowledge and attitudes of adolescents about premarital sexuality at Private Vocational School Surabaya. Suggestions for the School to provide integrated 
sexual education with formal lessons, provide spiritual education according to student beliefs, and procure information media in leaflets, for example, wall magazines.

\section{ACKNOWLEDGMENT}

The authors would like to acknowledge the Headmaster of Private Vocational School Surabaya and all of the students who have participated in this study.

\section{CONFLICT OF INTEREST}

The authors declare that they have no conflict of interest.

\section{REFERENCES}

Azwar, S. (2013). Sikap Manusia: Teori dan Pengukurannya (2nd ed.). Pustaka Belajar.

Barik, A. L., Purwaningtyas, R. A., \& Astuti, D. (2019). The Effectiveness of Traditional Media (Leaflet and Poster) to Promote Health in A Community Setting in The Digital Era: A Systematic Review. Jurnal Ners Unair, 14(3). https://doi. org/http://dx.doi.org/10.20473/ jn.v14i3.16988

Condran, B., Gahagan, J., \& Isfeld-kiely, H. (2017). A scoping review of social media as a platform for multi-level sexual health promotion intervensions. 26(1), 26-37. https://doi.org/https://doi. org/10.3138/cjhs.261-A1

Damanik, A. V., Lasmawanti, S., Anggraini, N., \& Hardika, B. D. (2020). The Effect of Leaflet on Reproductive Health Media Accessing Behavior among Students in Medan North Sumatera. JHPB, 5(1).

Fatmawaty, R. (2017). Memahami Psikologi Remaja. JURNAL REFORMA. https://doi. org/10.30736/rfma.v6i2.33

Freeman, E., Howell-jones, R., Oliver, I., Randall, S., Ford-young, W., Beckwith, P., \& Mcnulty, C. (2009). Promoting chlamydia screening with posters and leaflets in general practice-a qualitative study. 9. https://doi.org/https://doi. org/10.1186/1471-2458-9-383

Hasibuan, R. (2013). Faktor-faktor yang
Mempengaruhi Kejadian Seks Pranikah Pada Remaja Putri di SMAN 1 Pagai Utara Selatan Kabupaten Kepulauan Mentawai. Pekanbaru: Universitas Riau.

Kementrian Kesehatan RI. (2016). Situasi Kesehatan Reproduksi Remaja. Pusat Data dan Informasi Kementrian Kesehatan RI.

Kusumaningrum, V. A. (2009). Perilaku Aborsi pada Remaja.

Kusumastuti, D. (2010). Hubungan antara Pengetahuan dengan Sikap Seksual Pranikah Remaja. Surakarta: Universitas Sebelas Maret.

Naedi. (2012). Gambaran Tingkat Pengetahuan Seks Bebas pada Remaja Kelas XI di SMA Negeri 1 Cileungsi Kabupaten Bogor. Jakarta: Universitas Indonesia.

Pratiwi, A. A. (2012). Hubungan Tingkat Pengetahuan Remaja Tentang Dampak Seks Bebas Dengan Perilaku Seksual Remaja di Desa Kweni Sewon Bantul.

Prawesti, I., Haryanti, F., \& Lusmilasari, L. (2018). Effect of Health Education Using Video and Brochure on Maternal Health Literacy. Belitung Nursing Journal, 4(6). https://doi.org/DOI: https://doi. org/10.33546/bnj.176

Rahmawati, C. D., \& Devy, S. R. (2018). Dukungan Sosial Yang Mendorong Perilaku Pencegahan Seks Pranikah Pada Remaja Sma X Di Kota Surabaya. Jurnal PROMKES, 4(2), 129. https://doi. org/10.20473/jpk.v4.i2.2016.129-139

Siregar, A. A. (2014). Pendidikan Seks oleh Orang Tua pada Remaja Akhir. Yogyakarta: Universitas Islam Negeri Sunan Kalijaga.

Syihabudin, A. (2018). Pengaruh Penyuluhan Kesehatan Metode Audio Visual Terhadap Tingkat Pengetahuan dan Sikap Remaja Laki-Laki tentang Bahaya Seks Bebas Di SMA Wachid Hasyim 2 Taman Sidoarjo. Surabaya.

Tuong, W., Larsen, E. R., \& Armstrong, A. W. (2014). Videos to influence : a systematic review of effectiveness of video- based education in modifying health behaviors. 218-233. https://doi.org/https://doi. org/10.1007/s10865-012-9480-7 